\title{
Primary Sources and Food Web Structure of a Tropical Wetland with High Density of Mangrove Forest
}

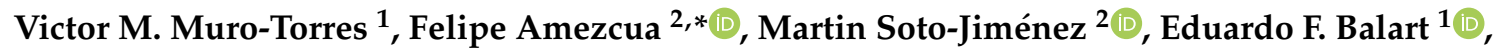 \\ Elisa Serviere-Zaragoza ${ }^{1}$, Lucinda Green ${ }^{3}$ and Jana Rajnohova ${ }^{3}$ \\ 1 CONACYT-Centro de Investigaciones Biológicas del Noroeste, Calle IPN \# 195, La Paz 23096, Mexico; \\ vmuro@cibnor.mx (V.M.M.-T.); ebalart04@cibnor.mx (E.F.B.); serviere04@cibnor.mx (E.S.-Z.) \\ 2 Instituto de Ciencias del Mar y Limnología, Universidad Nacional Autónoma de México, Joel Montes \\ Camarena s/n, Mazatlán, Sinaloa 82040, Mexico; martin@ola.icmyl.unam.mx \\ 3 Marine Biology Research Group, Ghent University, International MSc in Marine Biodiversity and \\ Conservation, Krijgslaan 281/S8, 9000 Ghent, Belgium; lucindasgreen@outlook.com (L.G.); \\ jana.rajnohova@gmail.com (J.R.) \\ * Correspondence: famezcua@ola.icmyl.unam.mx; Tel.: +52-669-985-2845
}

Received: 12 September 2020; Accepted: 7 October 2020; Published: 5 November 2020

\begin{abstract}
The trophic ecology of wetlands with mangrove forests remains poorly understood. Through the use of stomach contents analysis, stable isotope signatures, and Bayesian mixing models, the food web of a tropical wetland in the gulf of California was investigated. Consumers had heterogeneous diets, omnivores were the most abundant species $(47 \%)$, followed by planktivorous $(21 \%)$, minor piscivores $(10 \%)$, major piscivores $(10 \%)$, macrobenthivores $(9 \%)$, and herbivores $(3 \%)$. The values of $\delta^{13} \mathrm{C}$ (from -12 to $-29 \%$ ) and $\delta^{15} \mathrm{~N}$ (from 4 to $24 \%$ ) showed a wide range of isotopic values of the consumers. Most of the species had a broad isotopic niche and there was a large diet overlap of species due to the exploitation of a common set of food resources. Five trophic levels were identified, with the weakfish (Cynoscion xanthulus) as the top predator of this system with detritus coming from the mangrove as the main source that supports the food chain. This highlights the importance of the mangrove forests to such ecosystems, because not only they are the most important primary food source, but also, they offer habitat to a large suite of fauna, which are important components of the trophic chain.
\end{abstract}

Keywords: trophic level; stable isotopes; mangrove ecosystem

\section{Introduction}

Tropical wetlands with mangrove forests are highly threatened socio-ecological systems, where local communities rely heavily on aquatic animal protein, (such as fish and crustaceans), to meet food security [1]. These systems are biologically productive with a high rate of primary productivity supporting a high species diversity and exhibiting complex trophic webs [2-4] and have long been recognized to be major nursery areas for numerous commercially and ecological important consumers as fish, crustaceans, etc. [5,6]; for example, a high abundance of fish in these habitats has been explained by the ecosystem complexity, accessibility to the food sources, and lower risk of predation [7-9].

The function of mangroves as a potential source of food has been discussed in different investigations, some of them mention that mangrove organic matter provides important nutrition to aquatic communities [10-14]. In contrast, other research indicates that carbon derived from mangroves is less important as an energy source for aquatic food webs in comparison to other primary sources [15-21].

The hypothesis that mangroves contribute little to food webs is discussed in several studies that have used stable isotope analysis of carbon and nitrogen in systems dominated by mangroves. 
These investigations mention that the isotopic values in consumer tissues are deemed too distant to directly relate the biomass of the consumer with the assimilated mangrove $[4,15,17,22-24]$. In this context, microphytobenthos (available in detritus), macroalgae, and phytoplankton that are more carbon-rich, with higher nutritional quality and easily available to consumers compared to mangrove litter have been suggested as the most important primary sources $[4,25]$. However, despite decades of research on this topic, the relative importance of different primary sources supporting secondary productivity in estuarine ecosystems is still rather uncertain, because most of their results are inconclusive.

In the American Pacific one of the most important regions in regard to the abundance and density of mangrove forests associated with estuarine systems is Marismas Nacionales (Mexican Pacific), nevertheless, there is still a paucity of basic food web studies for these mangrove zones. The few studies devoted to elucidate the food web associated to lagoon-estuarine systems in this area had a quite different approach, as the Ecopath approach [26], as trophic biomagnification of trace metals [27,28], or trophic relations within food webs $[4,29,30]$. Then, it becomes crucial to study the food web structure and energy flows to understand the functioning of mangrove ecosystems, which are changing with the growing pressure from the human activity. These kinds of studies provide basic information on food sources, trophic interactions between species, energy flows from primary producers to consumers of different trophic levels (TL), and allow the understanding of the ecosystems functioning. The objective of this study was to determine food sources and identify different food webs of an estuarine system with a high mangrove density from the region of Marismas Nacionales, based on the application of stomach contents analysis (SCA), stable isotope analysis (SIA), and isotope mixing models (IMM) as tools to quantify contributions from sources to consumers. We propose the hypothesis that the direct contribution of the mangrove forests is low in comparison to the different primary sources that sustain the food web of this ecosystem, but also that the mangroves play an important role because of their structural complexity, which is essential for many species of fish and macroinvertebrates which eat and prey within this mangrove structure.

\section{Materials and Methods}

\subsection{Study Area}

The study was conducted in the tropical wetland of Teacapan, situated in the northern part of Marismas Nacionales complex, SE Gulf of California. It has a $1 \mathrm{~km}$ long-9 $\mathrm{m}$ deep inlet that connects the system with the sea, and there are two rivers that drain into this system all year round (Figure 1). The mean annual land temperature varies between 20 and $40{ }^{\circ} \mathrm{C}$, the average annual precipitation is $1459 \mathrm{~mm}$, and the evaporation rate is $1991 \mathrm{~mm} /$ year.

\subsection{Sample Collection and Processing}

A total of eight stations were sampled from August 2012 to October 2014 on a monthly basis. At each station all potential food sources were collected (mangrove, macroalgae, particulate organic matter (POM), sediment organic matter (SOM), and phytoplankton), as well as consumers (zooplankton, macrobenthos (polychaetes, bivalves, shrimps, and crabs), and fishes).

At each station particulate organic matter (POM), mixed phytoplankton, zooplankton, and suspended organic matter samples were collected with a plankton net with a mesh size of 30 and $200 \mu \mathrm{m}$. These were separated by filtering 500-2000 mL from water samples through a pre-combusted (500 C, $4 \mathrm{~h}$ ) glass fiber filter (GF/F) with a plastic syringe and then dried to a constant weight at $55{ }^{\circ} \mathrm{C}$ [31]. Superficial water samples were collected in $\mathrm{HCl}$-cleaned polyethylene $1 \mathrm{~L}$ bottles and suspended particulate matter (SPM) was separated by filtering. The upper layers $(5 \mathrm{~mm})$ of bottom sediments were collected at each sampling point using a Van Veen bottom $0.1 \mathrm{~m}^{2}$ grab sampler. From these sediments, polychaetes and other macrofaunal organisms were separated and sieved through a $0.5 \mathrm{~mm}$ mesh. 


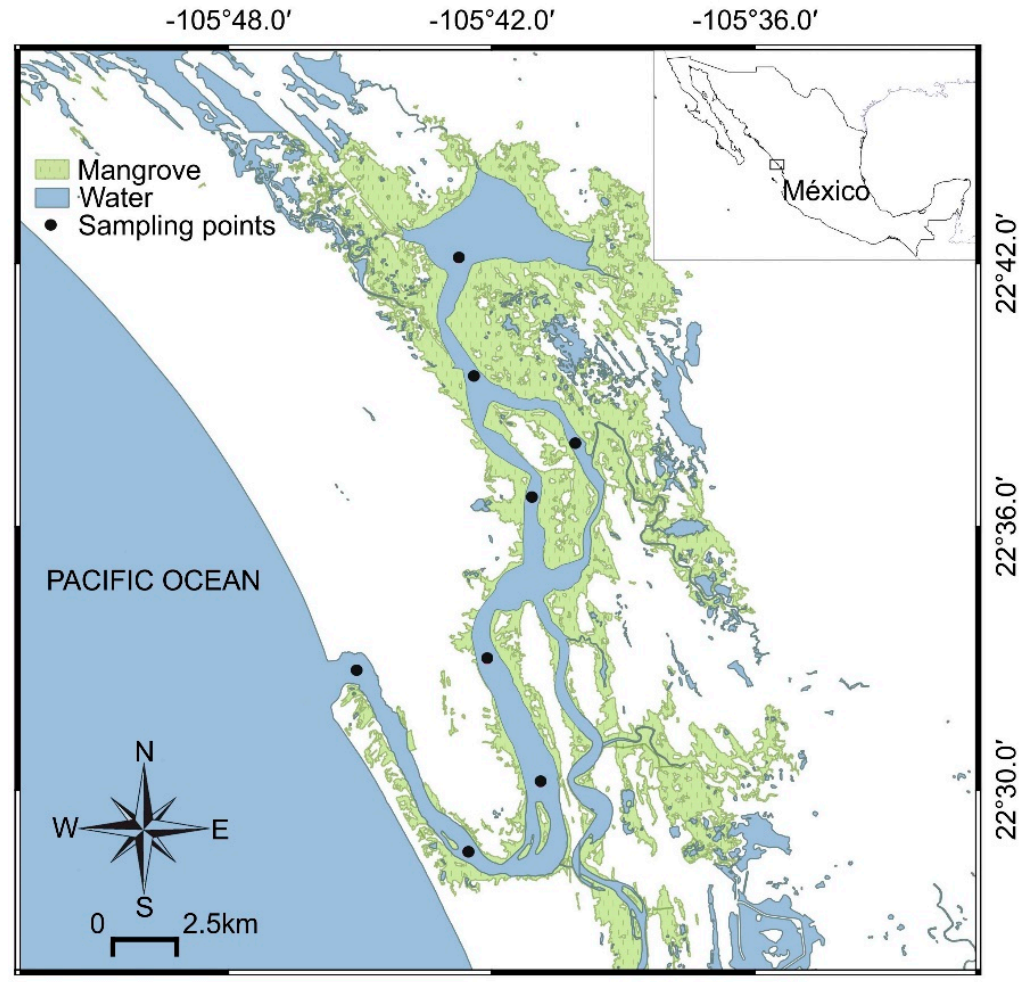

Figure 1. Map of the studied area. Black dots indicate sampling stations.

At the mangrove area closest to each sampling station, green and senescent mangrove leaves, macroalgae, snails, and crabs associated with mangrove roots were collected by hand. Macroinvertebrates and fish were captured with a gillnet of 3.5 inches of mesh size, which was left adrift for $20 \mathrm{~min}$. After that, the catch was sorted, put in plastic bags, and iced for their transportation to the laboratory. Only the most abundant and frequent species were used for the analysis and construction of the trophic food web, these are marked by * in Table S1.

\subsection{Feeding Habits (Stomach Contents Analysis)}

Stomach contents of macroinvertebrates and fish were processed according to [4]. The index of relative importance (IRI) was calculated with the formula IRI $=(\% \mathrm{~N}+\% \mathrm{~W}) \times(\% \mathrm{~F})$, where $\% \mathrm{~N}$ and $\% \mathrm{~W}$ represent the food items' numbers and wet weights, respectively. The frequency of occurrence $(\% \mathrm{~F})$ of each food item (presence-absence) in all stomachs that contained food [32] and subsequently modified as a percentage [33].

Multivariate analyses were used to statistically check whether the different species could be grouped according to their feeding habits and TL. To do this, a matrix was constructed that included predators in the columns and the prey items as rows, and the IRI as values. The data were square root transformed to reduce the effect of very abundant prey on the analysis whilst retaining the quantitative nature of the data, and transformed to a resemblance matrix. Two factors were assigned to group the predators according to their feeding guild (herbivore, detritivore, omnivore, planktivorous, carnivore 1, carnivore 2, and carnivore 3), and their TL (1.65-2 = Low, 2.1-3 = Medium, 3.1-5 = High). A permutational MANOVA (PERMANOVA) and a principal coordinates analysis (PCO) [34] were undertaken in order to test the null hypothesis that the feeding habits of the different fish species is not different according to the factors utilized [4].

\subsection{Stable Isotopes Analysis (SIA)}

Isotopic analyses included seston, detritus, phytoplankton/zooplankton, macroalgae, angiosperms, macrofaunal benthic organisms, and the most abundant species of macroinvertebrates and fish in the 
system. Sample processing for the isotopic studies were done according to the methodology previously described [4].

Values of $\delta^{13} \mathrm{C}$ and $\delta^{15} \mathrm{~N}$ were used to determine whether differences exist in the isotopic signals according to season and feeding guild through a Kruskal-Wallis ANOVA. Two seasons were identified, the hot and rainy season (September to November), and the dry and cold season (December through March). The feeding guilds were the same as previously explained.

\subsection{Trophic Position (TP)}

Since consumers were collected from two sources (pelagic and benthic), each with a separate set of primary producers and detritus, we used the equation of Post [34] to calculate the trophic position SIANC (stable isotope analysis in carbon and nitrogen) for all fish and macroinvertebrates species, taking into account that the proportion $\mathrm{N}$ in the consumer is derived from both sources in the trophic network:

$$
\mathrm{TP}_{\text {SIANC }}=\lambda+\left(\delta^{15} \mathrm{~N}_{\mathrm{C}}-\left[\delta^{15} \mathrm{~N}_{\text {base } 1} \times \alpha+\delta^{15} \mathrm{~N}_{\text {base } 2} \times(1-\alpha)\right]\right) / \Delta^{15} \mathrm{~N}
$$

where $\lambda$ is the trophic level of the base of the food web, $\delta^{15} \mathrm{~N}_{C}$ is the isotopic value of nitrogen in the consumer, $\delta^{15} \mathrm{~N}_{\text {base1 }}$ and $\delta^{15} \mathrm{~N}_{\text {base2 }}$ are mean $\delta^{15} \mathrm{~N}$ values of food web 1 (pelagic) and 2 (benthic) baselines, respectively, and $\Delta^{15} \mathrm{~N}$ is the fractionation of $\mathrm{N}$ between each trophic level. $\alpha$ was estimated following a two-endmember-mixing model that distinguishes both sources of carbon or energy:

$$
\alpha=\left(\delta^{13} C_{C}-\delta^{13} C_{\text {base } 2}\right) /\left(\delta^{13} C_{\text {base1 }}-\delta^{13} C_{\text {base } 2}\right)
$$

where $\delta^{13} C_{\text {base1 }}$ and $\delta^{13} C_{\text {base2 }}$ are mean of $\delta^{13} \mathrm{C}$ pelagic and benthonic, respectively [35]. Four primary sources were considered: (1) Phytoplankton, (2) seston and detritus, (3) benthic macroalgae, and (4) mangroves. Several investigations have used a trophic fractionation value of the nitrogen isotope that fluctuates between 2 and $4 \%$ o, (i.e., [25,34-36]). An assumed value of $\mathrm{F}=3.4 \%$ o was used in this study [36].

\subsection{Food Web Structure}

To determine the trophic structure of this wetland, the most abundant species of macroinvertebrates and fish that were present throughout the year were taken into account (Table S1). In order to describe the hierarchy and build a detailed quantitative flow for the food web, an approach that combines data from SCA and SIA was used. First, we began with a simple connectivity web by identifying the presence or absence of food items through stomach contents analysis; second, we transformed the connectivity web into a diet proportion web based on the fraction of each food found in the SCA; and third, based on SIA results, we estimated the proportion of each prey in the diet of each consumer using a Bayesian mixing model stable isotope analysis in R (SIAR) v. 4.2 [37].

The Bayesian method SIBER (stable isotope Bayesian ellipses in R) was used to define the isotopic niche space among the different groups as a measure of their isotopic resource use area at the population level. This method is based on the two-dimensional isotopic space of $\delta^{13} \mathrm{C}$ and $\delta^{15} \mathrm{~N}$, and assessed using the Bayesian analysis of standard ellipses; unlike the Euclidean methods, this analysis can incorporate uncertainties such as sampling biases and small sample sizes into niche metrics [38]. A Monte Carlo simulation to correct the bivariate ellipses $\left(\delta^{13} \mathrm{C}\right.$ and $\left.\delta^{15} \mathrm{~N}\right)$ was used, surrounding the data points in the $95 \%$ confidence interval for the distributions of both stable isotopes [39]. The results of both producers and consumers were plotted in $\delta^{13} \mathrm{C}$ vs. $\delta^{15} \mathrm{~N}$ diagrams to analyze differences in diet and trophic position between the different animal groups. Additionally, two-dimensional $\left(\delta^{13} \mathrm{C}\right.$ and $\delta^{15} \mathrm{~N}$ ) probabilistic (95\%) regions for each of the groups identified using a Bayesian framework in the package "nicheROVER" [40]. This package was used to calculate the probability overlap of isotope niche regions by pairs, providing directional estimates of niche overlap, accounts for groups (primary sources and consumers) distributions in multivariate niche space, and produces unique and consistent bivariate projections of the multivariate niche region. The niche region is defined as the joint 
probability density function of the multidimensional niche indicators at a user-defined probability alpha (in this study 95\%) [40].

\section{Results}

Primary sources collected included phytoplankton, detritus/seston, two mangrove species (Rizophora mangle and Laguncularia racemosa), and three species of macroalgae (Gracilaria vermiculophylla, Caulerpa sertularoides, and Ulva lactuca). Consumers included zooplankton (copepods constituted the $70 \%$, the rest was composed by euphausiids, chaetognatha, fish larvae, and siphonophores), macroinvertebrates (bivalves (Crassostrea cortezienzis and Mytella strigata), snail (Littoraria pintado), barnacles (Fistulobalanus dentivarians), polychaetes (Streblospio benedecti), crabs (Callinectes arcuatus, Portunus asper, Aratus sp., and Uca sp.), and shrimp (Litopenaeus vannamei)). Fish represented the most important group in relation to their abundance; 72 fish species were identified, belonging to 24 families. One fish species was classified as abundant, 17 as frequent, 29 as common, and 24 as rare species (Figure 2).

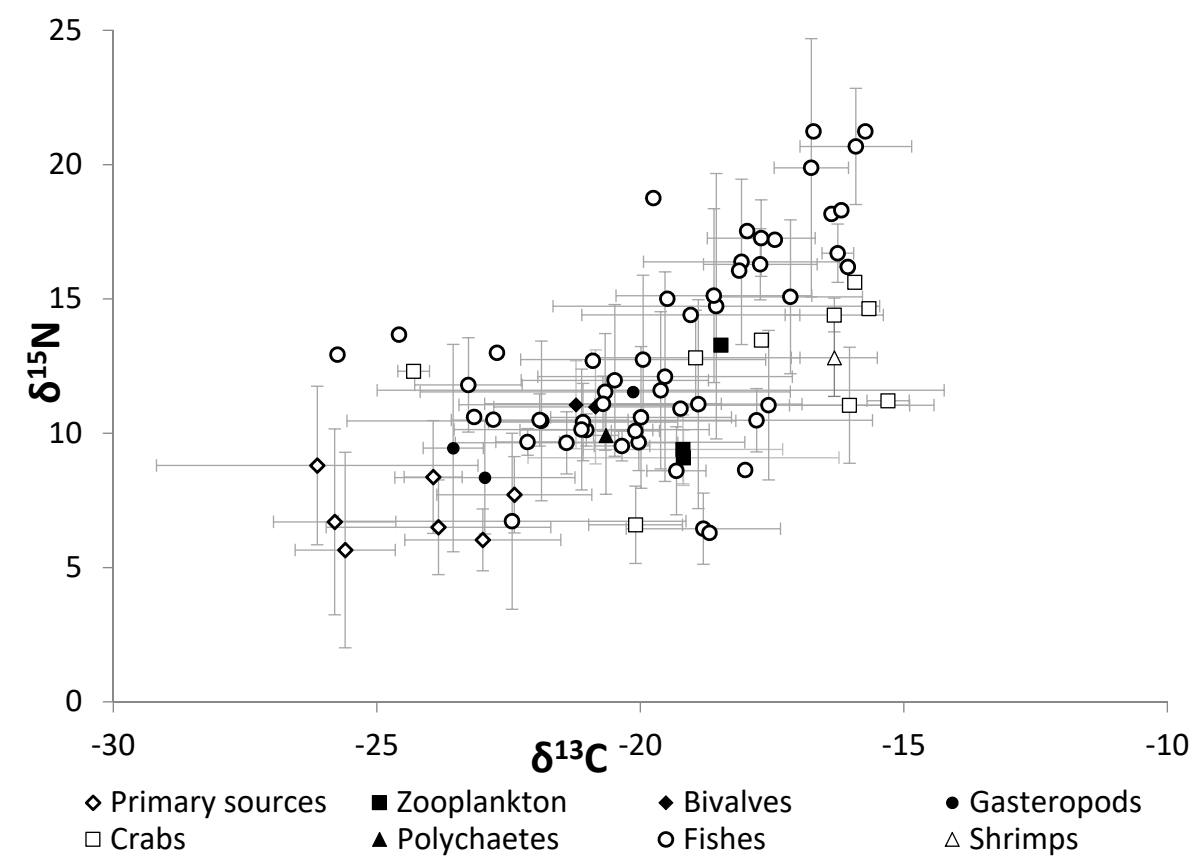

Figure 2. Relationships between mean $\delta^{13} \mathrm{C}(\% \mathrm{o})$ versus mean $\delta^{15} \mathrm{~N}(\% \mathrm{o})$ in food sources (primary producers) and predators (zooplankton, macroinvertebrates, and fish) in the wetland of Teacapan.

\subsection{Feeding Habits}

The stomach contents of 1324 organisms of the most frequent and abundant species of fish and macroinvertebrates were analyzed with multivariate analyses. From these, $26 \%$ were empty and were not considered for the analyses. The omnivores were the most abundant feeding guild in this system $(47 \%)$, followed by planktivorous $(21 \%)$, carnivores $2(10 \%)$, carnivores $3(10 \%)$, carnivores $1(9 \%)$, and herbivores (3\%) (Figure 2).

The oyster (C. cortezienzis), the mussel (M. strigata), and the herring (O. libertate) were planktivorous, for both zoo and phytoplankton. Anchovies and sardines feed mostly on plankton but also on detritus/seston. The polychaete (S. benedicti) and the mullets (Mugilidae), the Pacific anchoveta (C. mysticetus) and the milkfish (C. chanos) preyed on plankton as well as on detritus. The snail (L. pintado) preyed on macroalgae. A suite of predators which were initially considered as detritivore and omnivores, preyed on benthic species such as infaunal crustaceans, polychaetas, echinoderms, bivalves, and decapoda crustaceans. These included crabs, shrimps, and different species of demersal fishes. Species considered as carnivores 1 (cat fish and grunt) preyed mainly on decapoda. Carnivores 
2, which included a catfish and two species of jacks, preyed mostly on shrimps and prawns, and the carnivores 3 preyed mainly on fish and cephalopods, although these were not found in the system. These included snappers, snook, and weakfish (Table S1, Figure 3).

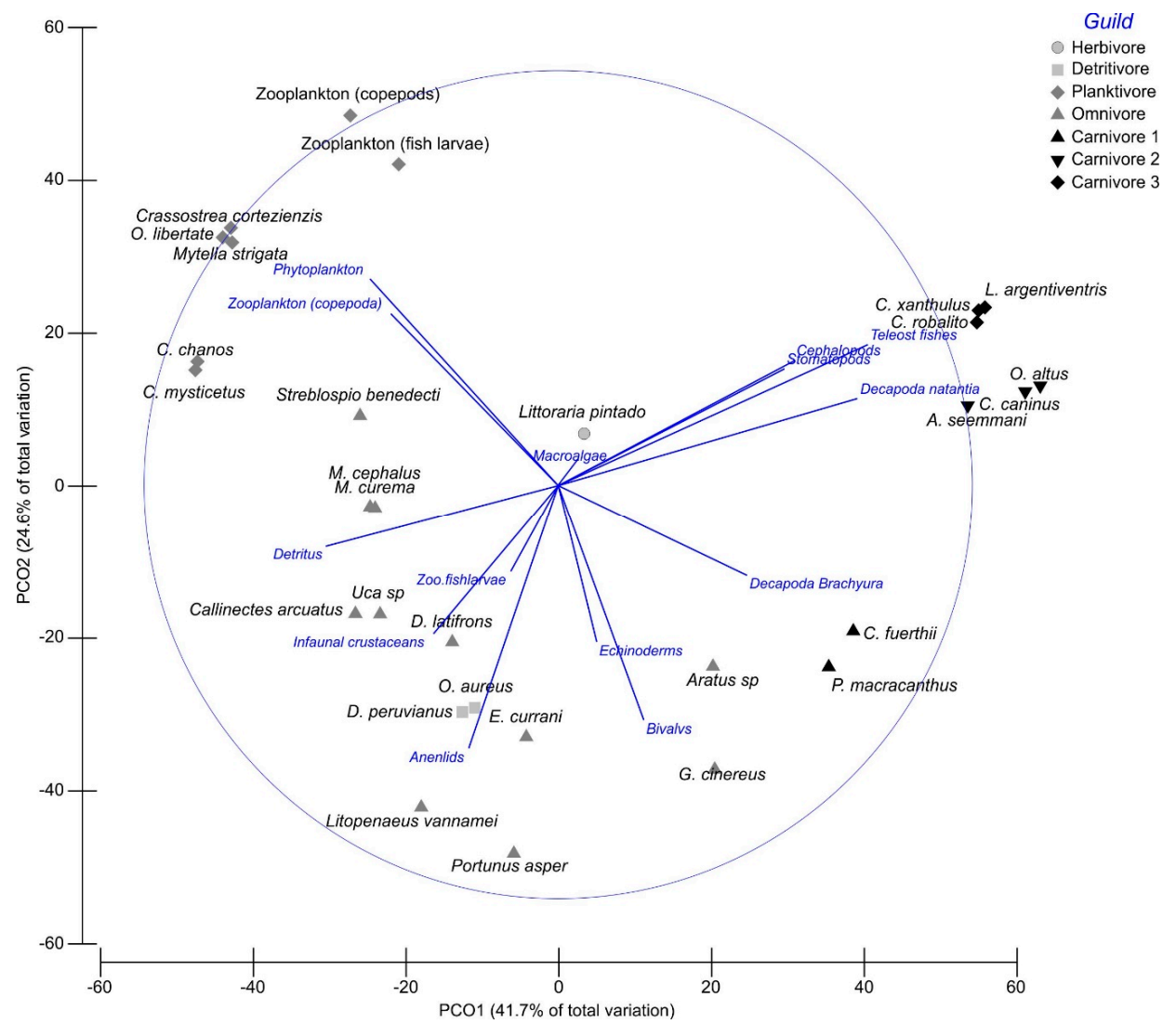

Figure 3. Principal coordinates analysis (PCO) showing the predators and their a priori designated feeding guild analyzed in the studied wetland. The vectors indicate the most important prey items for each group of predators.

Differences were found according to PERMANOVA in relation to the feeding guild (Pseudo- $\mathrm{F}_{2,17}=7.34, p<0.01$ ). The pairwise comparison test (Table 1 ) shows that with the exception of carnivores 2 and carnivores 3 , and detritivores and omnivores, all the guilds were different among them.

Table 1. Permutational MANOVA (PERMANOVA) results of the pairwise comparisons of the diet of the different feeding guilds analyzed for stomach contents analysis (SCA).

\begin{tabular}{ccc}
\hline Groups & $\mathbf{t}$ & $\boldsymbol{p}$-Value \\
\hline Carnivore 2, Carnivore 1 & 3.7035 & 0.01 \\
Carnivore 2, Carnivore 3 & 1.0591 & 0.38 \\
Carnivore 2, Planktivore & 8.3074 & 0.00 \\
Carnivore 2, Detritivore & 8.0119 & 0.00 \\
Carnivore 2, Omnivore & 4.0007 & 0.00 \\
Carnivore 1, Carnivore 3 & 4.3625 & 0.01 \\
Carnivore 1, Planktivore & 5.5486 & 0.01 \\
Carnivore 1, Detritivore & 3.6465 & 0.02 \\
Carnivore 1, Omnivore & 2.0959 & 0.05 \\
Carnivore 3, Planktivore & 9.265 & 0.00 \\
Carnivore 3, Detritivore & 10.364 & 0.00 \\
Carnivore 3, Omnivore & 4.1795 & 0.00 \\
Planktivore, Detritivore & 4.4535 & 0.01 \\
Planktivore, Omnivore & 2.4284 & 0.03 \\
Detritivore, Omnivore & 0.53857 & 0.73 \\
\hline
\end{tabular}




\subsection{Isotopic Niche}

In total, 302 samples of biological material were isotopically analyzed, representing species at all the trophic levels (from primary producers to Carnivores 3) (Table S1).

According to the carbon isotopic composition, the primary producers in this system are a combination of benthic macroalgae and mangrove (C3 type photosynthetic mechanism), phytoplankton (photosynthetic mechanism of type $\mathrm{C} 3$ and $\mathrm{C} 4$ ), seston, and detritus. For primary producers the values of $\delta^{13} \mathrm{C}$ were from -29.66 to $-16.70 \%$, the most negative values corresponding to the mangrove, detritus, and phytoplankton while the highest values corresponded to the macroalgae (Figure 3). Values of $\delta^{13} \mathrm{C}$ for the organic matter in detritus suggested that the origin is mostly mangrove contribution because they have very close values. The concentration of $\delta^{15} \mathrm{~N}$ values varied from 3.55 to $11.46 \%$ o without significant differences between the different types of primary producers (Kruskal-Wallis; $p>0.05$ ). Isotopic values of $\delta^{13} \mathrm{C}$ in zooplankton (copepods) ranged from -22.28 to $-16 \%$ and from 8.05 to $13.26 \%$ o with respect to $\delta^{15} \mathrm{~N}$ (Figure 4). The macroinvertebrates showed values of $\delta^{13} \mathrm{C}$ between -23.65 and $-16.32 \%$, while $\delta^{15} \mathrm{~N}$ varied from 6.73 to $14.94 \%$; gastropods and bivalves recorded the most impoverished values, and the decapods (crabs and shrimps) the highest values in both isotopes. The fish values of $\delta^{13} \mathrm{C}$ and $\delta^{15} \mathrm{~N}$ showed the widest range of registered isotopic values with a $\delta^{13} \mathrm{C}$ from -23.57 to $-15.84 \%$ in $\delta^{13} \mathrm{C}$ and from 4.58 to $24 \%$ in $\delta^{15} \mathrm{~N}$ (Figure 3). There were no significant differences between the rainy and dry season (Mann-Whitney $\mathrm{U}$ test, $p>0.05$ ).

The isotopic space of the primary sources and of the consumers varied according to the origin, aspects of the diet, and the habitat of the consumers over time. Measurements of total area (convex hulls) and standard ellipse areas (SEAc) of isotopic spaces obtained with SIBER were generally large for all groups (Figure 4, Table 2). Relative to the time of year, primary sources and consumers have a broad niche of isotopes (SEAc $=29.9$ and $29.2 \%$ o for rain and dry, respectively) with an overlap of over $90 \%$. Regarding the primary sources, the projected overlap of the mangrove isotope spaces and detritus presented the highest probability of overlap (37.3 and 89.4\%) indicating an isotopic relationship between both sources, followed by phytoplankton and macroalgae presented the probability of overlap lower isotopic occupying a different isotopic space than the other primary sources (Table 2). Although Figure 4 shows that phytoplankton has the largest overlap with mangrove and detritus, it is necessary to consider that the results from Table 2 are based on a Bayesian framework, which provide a statistical probability of overlap of the two dimensions (carbon and nitrogen isotopes), hence the difference between the table and what is observed in the graph.

The isotopic niche of consumers according to the taxonomic group presented a SEAc that varied from $7.3 \%$ o for gastropods to $29.6 \%$ o for fish, with high isotopic overlaps between them in general. Regarding the type of feeding, the SEAc obtained varied between 20.8 and 30.7\%o with niches overlaps greater than $60 \%$, except for herbivores that registered a SEAc of $2.2 \%$ ond overlap less than $20 \%$ (Figure 3, Table 2). This high overlap of niches indicates that consumers share resources that occupy similar isotopic spaces.

The isotopic space of the primary sources and predators varied according to their origin, feeding habits, and habitat. Convex hulls and SEAc of the isotopic spaces obtained with SIBER were large for all groups analyzed (Figure 4, Table 2).

In relation to season, primary sources and predators have a wide isotopic niche (SEAc $=29.9$ and $29.2 \%$ o for rainy and dry seasons, respectively), with an overlap of over $90 \%$. Mangrove and detritus isotopic spaces showed the highest overlap indicating that there is an isotopic relationship between both sources. On the other hand, phytoplankton and algae showed the lower isotopic overlap, thus occupying a different isotopic space than all other primary sources. Consumers' isotopic niche showed a SEAc, which varied from $7.3 \%$ o for gastropods to $29.6 \%$ o for fish, with a high isotopic overlap between them (Table 2).

In terms of feeding habits, SEAc varied between 20.8 and 30.7\%o with overlaps above $60 \%$ in some cases. Except for herbivores which showed a SEAc of 2.2\%o and overlaps below $20 \%$. These values indicate that predators share resources occupying similar isotopic spaces. 

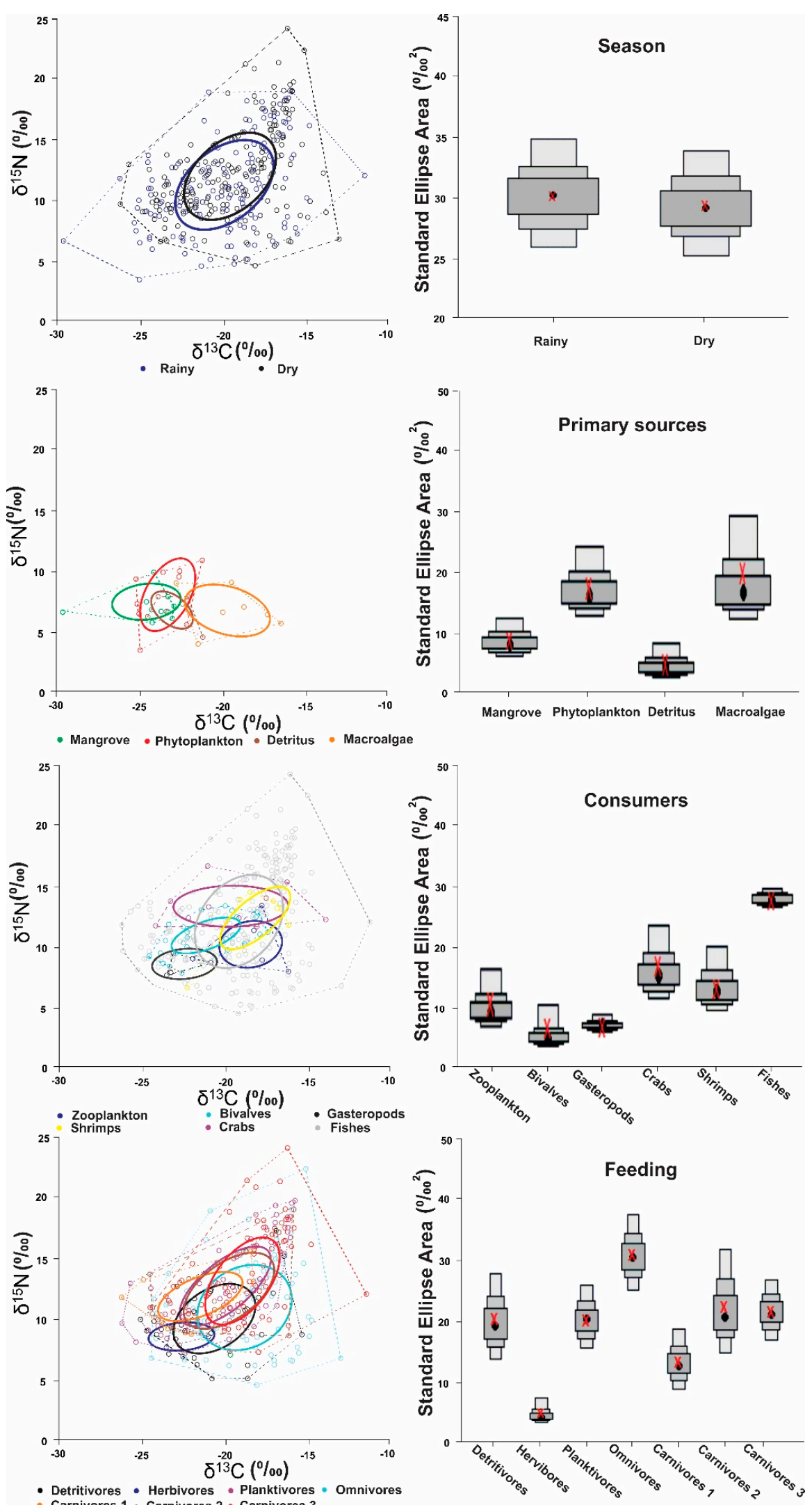

Figure 4. Comparison of the area of the isotopic niches by groups: Between season for all species, primary sources, consumers (taxonomic group), and feeding guild. Rectangles represent the 50,75, and $95 \%$ credible intervals (dark to light shading, respectively), and black dots represent the mode values. 
Table 2. Total area (convex hulls), mean standard ellipses areas of two-dimensional niches region, mean overlap probability of $95 \%$ niche regions (probability of group A overlapping with group B), and $95 \%$ credible intervals of each group.

\begin{tabular}{|c|c|c|c|c|c|c|}
\hline \multirow{3}{*}{$\begin{array}{c}\text { Category } \\
\text { Season }\end{array}$} & \multirow{3}{*}{$\begin{array}{c}\text { Group } \\
\text { Rainy } \\
\text { Dry }\end{array}$} & \multirow{3}{*}{$\begin{array}{c}\text { TA } \\
166.6 \\
155.7\end{array}$} & \multirow{3}{*}{$\begin{array}{c}\text { SEA }_{\mathbf{C}} \\
29.9 \\
29.2\end{array}$} & \multicolumn{2}{|c|}{$\begin{array}{c}\text { Mean Overlap Probability } \\
(\%)\end{array}$} & \multirow{2}{*}{$\begin{array}{c}\mathbf{9 5} \% \text { CI } \\
90-97\end{array}$} \\
\hline & & & & Dry & 94.4 & \\
\hline & & & & Rainy & 93.8 & $90-97$ \\
\hline \multirow{12}{*}{$\begin{array}{l}\text { Primary } \\
\text { sources }\end{array}$} & \multirow{3}{*}{ Detritus } & \multirow{3}{*}{3.7} & \multirow{3}{*}{5.2} & Phytoplankton & 34.9 & $15-71$ \\
\hline & & & & Macroalgae & 10.4 & $0-38$ \\
\hline & & & & Mangrove & 37.2 & $15-66$ \\
\hline & \multirow{3}{*}{ Phytoplankton } & \multirow{3}{*}{19.7} & \multirow{3}{*}{14.6} & Detritus & 88.9 & 50-100 \\
\hline & & & & Macroalgae & 63.9 & $30-95$ \\
\hline & & & & Mangrove & 79.5 & $51-99$ \\
\hline & \multirow{3}{*}{ Macroalgae } & \multirow{3}{*}{18.4} & \multirow{3}{*}{17.2} & Detritus & 57.1 & $56-100$ \\
\hline & & & & Phytoplankton & 44.5 & $59-99$ \\
\hline & & & & Mangrove & 53.9 & $37-97$ \\
\hline & \multirow{3}{*}{ Mangrove } & \multirow{3}{*}{13.3} & \multirow{3}{*}{9.5} & Detritus & 89.4 & $1-98$ \\
\hline & & & & Phytoplankton & 83.7 & $27-89$ \\
\hline & & & & Macroalgae & 70.2 & $26-86$ \\
\hline \multirow{30}{*}{ Consumers } & \multirow{5}{*}{ Bivalves } & \multirow{5}{*}{22.1} & \multirow{5}{*}{7.9} & Gasteropods & 80.2 & $32-100$ \\
\hline & & & & Shrimps & 54.1 & $23-81$ \\
\hline & & & & Zooplankton & 37.3 & $12-66$ \\
\hline & & & & Crabs & 48.5 & $22-75$ \\
\hline & & & & Fishes & 43.3 & $33-57$ \\
\hline & & & & Bivalves & 22.3 & $5-61$ \\
\hline & & & & Shrimps & 6.1 & $0-23$ \\
\hline & Gasteropods & 2.0 & 7.3 & Zooplankton & 14.7 & $1-58$ \\
\hline & & & & Crabs & 2.2 & $0-13$ \\
\hline & & & & Fishes & 10.3 & $3-24$ \\
\hline & & & & Bivalves & 62.1 & $31-91$ \\
\hline & & & & Gasteropods & 38.6 & $0-98$ \\
\hline & Shrimps & 18.7 & 13.5 & Zooplankton & 45.4 & $11-90$ \\
\hline & & & & Crabs & 52.6 & $24-83$ \\
\hline & & & & Fishes & 53.3 & $33-76$ \\
\hline & & & & Bivalves & 54.1 & 14-93 \\
\hline & & & & Gasteropods & 55.1 & $2-100$ \\
\hline & Zooplankton & 14.5 & 10.4 & Shrimps & 33.1 & $7-74$ \\
\hline & & & & Crabs & 19.7 & $1-66$ \\
\hline & & & & Fishes & 36.4 & $20-65$ \\
\hline & & & & Bivalves & 74.4 & $42-99$ \\
\hline & & & & Gasteropods & 19.5 & $0-98$ \\
\hline & Crabs & 31.6 & 17.9 & Shrimps & 76.2 & $43-98$ \\
\hline & & & & Zooplankton & 33.7 & 2-91 \\
\hline & & & & Fishes & 58.2 & $43-85$ \\
\hline & & & & Bivalves & 98.6 & 95-100 \\
\hline & & & & Gasteropods & 96.9 & 70-100 \\
\hline & Fishes & 175.9 & 29.6 & Shrimps & 97.4 & 80-100 \\
\hline & & & & Zooplankton & 92.4 & $71-100$ \\
\hline & & & & Crabs & 90.1 & 73-99 \\
\hline
\end{tabular}


Table 2. Cont.

\begin{tabular}{|c|c|c|c|c|c|c|}
\hline & & & SEA $_{C}$ & \multicolumn{2}{|c|}{$\begin{array}{c}\text { Mean Overlap Probability } \\
(\%)\end{array}$} & $\begin{array}{l}95 \% \mathrm{C} \\
70-100\end{array}$ \\
\hline & Detritivores & 66.6 & 22.6 & $\begin{array}{c}\text { Herbivores } \\
\text { Planktivores } \\
\text { Omnivores } \\
\text { Carnivores } 1 \\
\text { Carnivores } 2 \\
\text { Carnivores } 3\end{array}$ & $\begin{array}{c}97.1 \\
80.4 \\
78.2 \\
91.4 \\
82.9 \\
77\end{array}$ & $\begin{array}{c}70-100 \\
64-92 \\
65-90 \\
77-99 \\
65-95 \\
62-89\end{array}$ \\
\hline & Herbivores & 2.1 & 2.7 & $\begin{array}{c}\text { Detritivores } \\
\text { Planktivores } \\
\text { Omnivores } \\
\text { Carnivores } 1 \\
\text { Carnivores } 2 \\
\text { Carnivores } 3\end{array}$ & $\begin{array}{c}18.8 \\
10.9 \\
8.5 \\
11.7 \\
10.6 \\
7.4\end{array}$ & $\begin{array}{l}6-41 \\
4-23 \\
2-22 \\
2-31 \\
3-25 \\
2-18\end{array}$ \\
\hline & Planktivore & 68.9 & 20.8 & $\begin{array}{c}\text { Detritivores } \\
\text { Herbivores } \\
\text { Omnivores } \\
\text { Carnivores } 1 \\
\text { Carnivores } 2 \\
\text { Carnivores } 3\end{array}$ & $\begin{array}{c}81 \\
95.4 \\
67.1 \\
93.5 \\
90.8 \\
88.7\end{array}$ & $\begin{array}{c}65-92 \\
66-100 \\
56-79 \\
84-99 \\
80-98 \\
80-95\end{array}$ \\
\hline \multirow[t]{4}{*}{$\begin{array}{l}\text { Feeding } \\
\text { guild }\end{array}$} & Omnivores & 135.7 & 30.7 & $\begin{array}{c}\text { Detritivores } \\
\text { Herbivores } \\
\text { Planktivores } \\
\text { Carnivores } 1 \\
\text { Carnivores } 2 \\
\text { Carnivores } 3\end{array}$ & $\begin{array}{l}95.1 \\
95.2 \\
92.7 \\
93.5 \\
94.4 \\
93.6\end{array}$ & $\begin{array}{c}88-99 \\
59-100 \\
86-98 \\
84-99 \\
85-99 \\
87-98\end{array}$ \\
\hline & Carnivores 1 & 74.6 & 20.63 & $\begin{array}{c}\text { Detritivores } \\
\text { Herbivores } \\
\text { Planktivores } \\
\text { Omnivores } \\
\text { Carnivores } 2 \\
\text { Carnivores } 3\end{array}$ & $\begin{array}{l}66.3 \\
82.9 \\
76.5 \\
52.2 \\
74.7 \\
66.9\end{array}$ & $\begin{array}{c}48-85 \\
27-100 \\
63-90 \\
37-69 \\
57-91 \\
51-82\end{array}$ \\
\hline & Carnivores 2 & 72.4 & 21.3 & $\begin{array}{c}\text { Detritivores } \\
\text { Herbivores } \\
\text { Planktivores } \\
\text { Omnivores } \\
\text { Carnivores } 1 \\
\text { Carnivores } 3\end{array}$ & $\begin{array}{c}86.3 \\
95.1 \\
92.2 \\
75.3 \\
93 \\
90.4\end{array}$ & $\begin{array}{c}69-97 \\
62-100 \\
82-99 \\
59-89 \\
80-99 \\
79-98\end{array}$ \\
\hline & Carnivores 3 & 11.5.1 & 22.9 & $\begin{array}{c}\text { Detritivores } \\
\text { Herbivores } \\
\text { Planktivores } \\
\text { Omnivores } \\
\text { Carnivores } 1 \\
\text { Carnivores } 2\end{array}$ & $\begin{array}{l}85.3 \\
86.9 \\
90.2 \\
78.2 \\
84.9 \\
90.9\end{array}$ & $\begin{array}{c}70-95 \\
39-100 \\
82-96 \\
67-89 \\
70-96 \\
80-98\end{array}$ \\
\hline
\end{tabular}

\subsection{Trophic Position (TP) and Food Web Structure}

Through the combination of analysis of stomach contents analysis, stable isotopes, and Bayesian mixing model of stable isotopes, the structure and trophic position of the food chain in this system was elaborated. Isotopic values of $\delta^{13} \mathrm{C}$ and $\delta^{15} \mathrm{~N}$ allowed the estimation of five trophic levels (Figure 5). 


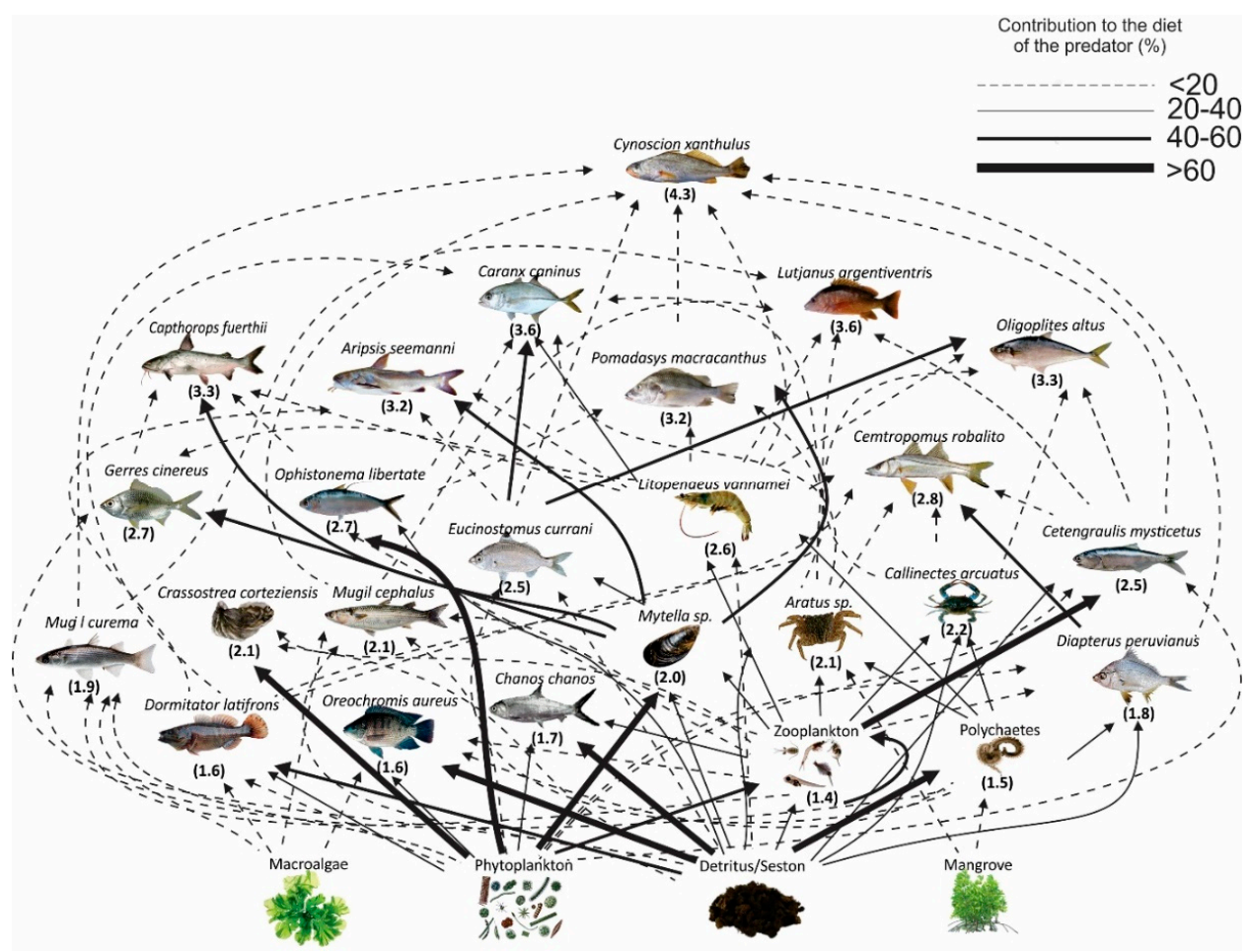

Figure 5. Trophic structure from the Teacapan wetland: The thickness of trophic links indicates the importance of that preys' contribution.

In the wetland of Teacapan, a large number of first order consumers exist who prey on the different primary producers. Four primary sources were identified supporting different trophic chains: Phytoplankton, detritus/seston, algae, and mangroves.

Phytoplankton is preyed upon by zooplankton, bivalves, and fish species such as sardines and anchovies. Detritus/seston are the basis for a food chain, which includes different primary consumers such as zooplankton, polychaetas, shrimps, crabs, and fish such tilapia and milkfish. This trophic chain is specially established in the roots of the mangroves. Macroalgae are the basis of another trophic chain composed at the basis by snails and some fish species such as the Pacific fat sleeper and mullets. Mangroves are directly consumed only by some species of crabs and polychaetas, although this does not constitute an important part of their diet. Most of these primary consumers have a TP below 2.

The former trophic chains get lost at the secondary and tertiary consumer level, as these predators' prey on a broad range of prey items and from different TP, thus increasing the complexity of the trophic chain in the system because of all the links and connections. In these TP there are some macroinvertebrates species and most of the fish species. In these levels, many species are omnivores such as crabs, shrimps, mullets, and mojarras preying on primary producers and also on first order consumers such as polychaeta and benthic mollusks. Omnivore species did not show a predominant food source, however, for this group primary producers had a significant contribution. In top predators (TP 3 and above) it is not possible to discern the sources of their trophic spectrum, as these organisms prey upon a large diversity of organisms.

Species that connect the primary producers to top trophic levels, and that can, therefore, be considered as keystone species were shrimps and crabs, connecting the benthos with the upper levels, whilst zooplankton, sardines, and bivalves connected the phytoplankton with the top trophic levels.

\section{Discussion}

Previous studies have already pointed out the high levels of primary productivity of wetlands with mangrove forests [41], and their importance as a primary food source supporting the food web in these ecosystems [5]. Since then, there have been studies reporting the importance of mangroves as 
the basis of coastal fish populations [42], while others reported that other primary producers, such as microphytobenthos, seagrass, and phytoplankton were more important primary food sources for mangrove fish communities [19,43-45]. However, none of the previously mentioned works have been undertaken in the gulf of California. These kinds of studies are needed to assess the role of different primary producers in supporting tropical wetland food chains with a high density of mangrove forests in the poorly studied wetlands of the gulf of California and Mexican pacific.

The complexity of the trophic structure of estuarine systems in the region has already been reported [4,35], however, no such studies exist for Marismas Nacionales complex of brine coastal lagoons, mangroves, swamps, and ravines.

In this study, we determined trophic grouping of the estuarine system of Teacapan (northern part of Marismas Nacionales complex) based on a combination of both stable isotopes and stomach contents analysis.

\subsection{Feeding Habits}

The SCA permitted an initial glimpse of the food web in the system, allowing us to identify groups of predators, and determine if the feeding guilds assigned a priori, corresponded to the actual feeding behavior of all the species analyzed. The only true herbivore was an alga feeding gastropod. Planktivorous species ate both phyto and zooplankton, although zooplankton species such as copepods and fish larvae ate predominantly phytoplankton, while others preyed as well on detritus and seston (polychaetas, milkfish, anchovies, and mullets). All the macroinvertebrates and a large amount of fish preyed on a suite of prey items including detritus, fish larvae, infaunal crustaceans, and benthic invertebrates. All these species, including the planktivorous and the a priori considered seston and detritus eaters, could be considered as omnivores, which were the majority of the species in the system. This high diversity of prey in the stomach contents probably match the diversity of available preys in this type of estuarine system [46]. It had been stated that dominant species adapted to estuarine systems are found together in great abundance in a restricted area, so there is a high overlap of diets when sharing a similar prey [47-49]. These species occupy a few trophic niches and therefore exploit a common set of resources, which causes a high overlap of species as recorded in this study. However, dietary overlap does not necessarily imply trophic competition, in this type of mangrove estuarine ecosystem there is a great abundance of resources that trophic competition between them is unlikely [50-52]. The success of the omnivore strategy against other feeding strategies is based on a broad dietary flexibility, which allows them to adjust possible fluctuations in the environment and therefore in resources. This strategy allows a very similar species to be found in a habitat occupying different trophic positions $[53,54]$ as observed in some species in our area of study, for example, Diapterus peruvianus and M. curema in estuarine areas feed mainly on detritus, whereas in marine areas their diet can change to omnivores [55,56].

Only fish species were true carnivores, and therefore placed at the top of the food chain in the estuarine system. These were a trophically diverse group, encompassing species of different sizes and diverse feeding strategies, as reported in other studies [6,46,52]. These top predators preyed on other fish (both pelagic and demersal), shrimps, and crabs as these species are usually the most abundant in estuarine and coastal ecosystems [57].

\subsection{Isotopic Niche}

The concept of ecological niche [58] has been embraced in isotopic ecology as isotope niche, since stable isotopes vary with aspects of the diet and habitat of consumers over time [59]. Isotopic variation within and between individuals of the same species or population reflects the amplitude of the isotope $[10,59,60]$. Therefore, the data of several organisms can give an estimate of the amplitude of the isotope niche at the population level.

The studied wetland system is characterized by a variety of sources of organic matter due to the input of subsidies by the surrounding environment and its high in situ production [61]. These sources 
varied not only spatially but temporally in terms of quantity and quality concerning their isotopic composition. This large variability of resources is one of the major problems for the analysis of trophic studies since it complicates their direct use as indicators of $\delta^{13} \mathrm{Cbase}$ and $\delta^{15} \mathrm{Nbase}$ to estimate the Trophic Position for consumers. However, this was not reflected in the studied wetland, since when comparing the isotopic signals of the organisms at different times of the year (rainy and dry) no significant differences were found between them.

Seasonal variation in the estuarine isotopic signatures is mainly related to the seasonal changes: When the fluvial contributions are stronger, it is expected that the terrestrial POM poor in $\delta^{13} \mathrm{C}$ influences the isotopic signatures of the estuarine species [62]. This wetland registers large fluvial contributions during the rainy season, therefore, significant changes were expected in the isotopic signatures of the primary producers and consumers, however, the seasonal differences were not pronounced enough to produce significant differences in the isotopic signatures of the various species between rain and drought seasons. Other authors showed that even in conditions of low fluvial contribution, the influence of the terrestrial POM is remarkable up to $30 \mathrm{~km}$ from the mouth of the river, which means that the POM of seawater enriched in $\delta^{13} \mathrm{C}$ probably does not have a great influence on the isotopic signatures of this estuary [61]. This is probably happening in this wetland.

Mangrove leaves and detritus were the most depleted in $8^{13} \mathrm{C}$ among the sources of primary producers analyzed, and its average $\delta^{13} \mathrm{C}$ values were close to those found in many mangrove ecosystems studies $[31,63,64]$. Except for benthic algae, primary producers in estuarine ecosystems generally exhibited low $\delta^{13} \mathrm{C}$ values.

The large isotopic niches found in this work indicate that macroinvertebrates and fish in this wetland use heterogeneous diets, which comprise a wide variety of food sources with different isotopic values, causing, a high isotopic overlap.

\subsection{Trophic Position (TP) and Food Web Structure}

In different studies, to determine the trophic structure of the species public databases such as FishBase are frequently used, however, this information may be strongly biased [35], in part because in estuarine systems such as Teacapan fish tend to be shorter than compared to those reported in this type of database. For this reason, in this investigation the trophic positions of the organisms were determined based on the results obtained with stable isotopes and stomach contents analysis.

It was possible to build a general model for the trophic network of this wetland from trophic links suggested by the analysis of stomach contents, stable isotopes, and the isotopic mixture model, where the main trophic chains that transport energy from the primary producers are represented. However, it is important to remark that the true food web is a more complex version than the one documented here.

Of our described trophic network, five trophic levels were identified, the first consisting of primary producers (seston, phytoplankton, macroalgae, detritus, and mangrove), the second by first-order consumers eating mainly detritus/seston and plankton in a lesser extent, the third level consisting of omnivorous species, the fourth trophic level formed by carnivorous species of first (macrobentophagous) and second order (piscivores), and the fifth level represented by a single species of corvine that is the top predator of the trophic network.

Detritus and particulate organic matter were grouped into a single source because other authors have reported that mangrove detritus has a greater than $50 \%$ contribution to particulate organic matter (POM) [10]. This possibly explains the unexpected coupling of the benthic and pelagic components as observed in the isotopic analyses.

Two main trophic chains were identified, the first one based on estuarine phytoplankton. This planktonic food chain transports energy from these suspended producers to small planktonic organisms such as zooplankton, as well as to macroinvertebrates such as bivalves (Mytella sp.) and some species of fish such as sardines (Ophistonema libertate); these species in turn contribute to the diet of fish of higher levels. Another trophic route based on detritus transports energy to detritivorous invertebrates 
such as polychaetes, crustaceans, and some fish such as tilapia (Oreochromis aureus), sleeper (Dormitator latifrons), and mojarra (Diapterus peruvianus), which in turn are consumed by macrobenthic carnivores (trophic level 3, Cathorops fuerthii and Pomadasys macracanthus), by second order carnivores (Centropomus robalito and Ariops seemanni), and third order (Caranx caninus, Lutjanus argentiventris, and Cynoscion xanthulus). There are other minor chains such as the benthic macroalgae that transport energy in less quantity by being part of the diet of some fish such as mullets (M. curema and M. cephalus), which in turn serve as an important part of the diet of the main piscivores (trophic levels 4 and 5: Caranx caninus, Lutjanus argentiventris, and Cynoscion xanthulus) (Figure 4). The contribution of the mangrove directly to the trophic chain is practically null, although it is consumed by polychaetes and some crabs in low proportion.

Since frequently different sources had a similar isotope composition, clear trophic links could not be traced for most species, mainly from upper trophic levels. Therefore, several combinations of potential sources can explain stable isotope values of the piscivores. However, in lower trophic levels it was possible to identify relative trophic links, for example, bivalve mollusks (Mytella sp.) and sardine (Ophistonema libertate) showed very strong trophic connections to phytoplankton, anchovy (Cetengraulis mysticetus) is strongly linked to the isotopic signal of zooplankton (copepods) and the isotopic composition of detritus is strongly linked to species such as tilapia (Oreochromis aureus), milkfish (Chanos chanos), and polychaetes, which suggests an important dependence on these sources.

\subsection{Importance of the Contribution of Mangroves}

The role of mangroves as a potential source of food has been discussed for a long time [41]. While some studies show that mangrove organic matter provides important nutrition to aquatic communities [10-14], other studies do not show a strong nutritional linkage between mangroves and consumers. There have been several attempts to compare interlinked mangrove, seagrass, and mudflat food webs through stable isotope analysis that have highlighted the low importance of mangrove litter as a food source for fish $[16,20,21]$.

As previously stated, the main source of detritus is mangrove [10], and in our study the recorded average $\delta^{13} \mathrm{C}$ for mangroves ( $-26.5 \%$ on average) and detritus $(-23.9 \%$ ) were very similar. Therefore, considering that the detritus was the base of an important trophic route in this system, mangrove contribution in this system is very important through the consumption of detritus released from the mangrove. This highlights the importance of the mangrove forests in this ecosystem, because besides being an important base of the food chain, they play, an important role in this ecosystem. The utilization of mangrove resource as feeding ground can be influenced by access and residency of organisms within the ecosystems [65], by different tidal ranges [43], mangrove setting [19], nutrient concentration according to seasonal changes [66], and presence of other coastal habitats as potential primary producers [16]. In the case of Teacapan, the mangrove presented the greatest overlap of isotopic niche with the detritus of the primary sources analyzed, therefore it can be deduced that the carbon coming from the mangroves in the form of detritus is an important carbon source for the food web; this is similar to what was reported in a study of aquatic consumers in a Biosphere Reserve in Southeastern México [29]. This might be due to the absence of more labile carbon sources such as seagrass or phytoplankton. Furthermore, the leaf litter productivity in mangroves persist throughout the year contrary to the algae or phytoplankton that occur only under the favorable environmental conditions. This wetland serves as a feeding ground mostly for mollusks, crabs, and fish, which reside permanently there and have direct access to the mangrove forests. In addition, these ecosystems serve as refugia for invertebrates and fish, and create substrate for a diversity of primary producers and consumers, thereby playing an important indirect role to the food web of these systems.

Due to the isotopic proportions that the primary producers show, it can be assumed that detritus is the main source that supports the food chain of Teacapan; however, an absolute conclusion cannot be drawn because for logistical reasons it was not possible to sample all the possible sources of the 
system. In general, there is no homogenous mangrove derived detritus food web but rather a diverse food web that supports the biomass of consumers.

\section{Conclusions}

This study further demonstrates the relative importance of various primary producers as organic matter sources supporting the diverse fish and invertebrate community in Teacapan estuary, and also points at the importance of mangroves for sustaining the food web in such ecosystems. There is a high level of diet overlap between different groups. Both fish and invertebrate appear to depend differently on different primary producers available, although mathe mangrove appear to be the most important primary source. The invertebrates had heterogeneous diets and many fish and macroinvertebrates fed on the mangrove detritus with few mangrove inhabitants such as polychaetes and grapsid crabs directly feeding on the mangrove leaves, which presents a low contribution to their diet; however, more studies are needed to give a more precise conclusion. Due to the ecological importance of wetlands with mangrove ecosystems, their proper management is necessary to conserve these ecosystems and ensure the maintenance of coastal fisheries, because most of the species collected in this study of macroinvertebrates and fish are of economic importance. The trophic position of the individual species and the general trophic structure of the community provide important tools to monitor the effects of human impacts, climate change, and the persistence and resilience of food webs.

Supplementary Materials: The following are available online at http://www.mdpi.com/2073-4441/12/11/3105/s1. Table S1: Feeding strategy, food items, isotopic composition of $\delta^{13} \mathrm{C}$ and $\delta^{15} \mathrm{~N}$ values (\%o, mean $\pm \mathrm{SD}$ ), and trophic position (TP) of the composite samples of seston, detritus, primary producers and main consumer species, and fish collected at the wetland of Teacapán. $\mathrm{N}=$ number of samples. A\% = relative abundance. $\mathrm{B} \%=$ relative biomass. The organisms marked with "**" were used for the construction of the trophic network.

Author Contributions: Conceptualization, V.M.M.-T., F.A., and M.S.-J.; methodology, V.M.M.-T., F.A., and M.S.-J.; software, V.M.M.-T., F.A., M.S.-J., and L.G.; validation, V.M.M.-T., F.A., and M.S.-J.; formal analysis, V.M.M.-T., F.A., and L.G.; investigation, V.M.M.-T. and F.A.; resources, V.M.M.-T., F.A., and M.S.-J.; data curation, V.M.M.-T., J.R., and L.G.; writing - original draft preparation, F.A., V.M.M.-T., J.R., E.F.B., E.S.-Z., and L.G.; writing-review and editing, F.A., V.M.M.-T., J.R., E.F.B., E.S.-Z., and L.G.; visualization, F.A.; supervision, F.A. and M.S.-J.; project administration, F.A.; funding acquisition, V.M.M.-T., F.A., and M.S.-J. All authors have read and agreed to the published version of the manuscript.

Funding: This research was funded by projects PAPIIT-UNAM IN217408 and IN215206.

Acknowledgments: We thank all the students and personnel who helped with the process and analysis of data. V.M. Muro-Torres thanks CONACYT for the Ph.D. grant.

Conflicts of Interest: The authors declare no conflict of interest. The funders had no role in the design of the study; in the collection, analyses, or interpretation of data; in the writing of the manuscript, or in the decision to publish the results.

\section{References}

1. Campos-Silva, J.V.; Peres, C.A. Community-based management induces rapid recovery of a high-value tropical freshwater fishery. Sci. Rep. 2016, 6, 1-13. [CrossRef]

2. Nagelkerken, I.; Blaber, S.J.M.; Bouillon, S.; Green, P.; Haywood, M.; Kirton, L.G.; Meynecke, J.O.; Pawlik, J.; Penrose, H.M.; Sasekumar, A.; et al. The habitat function of mangroves for terrestrial and marine fauna: A review. Aquat. Bot. 2008, 89, 155-185. [CrossRef]

3. Alongi, D.M. Carbon cycling and storage in mangrove forests. Annu. Rev. Mar. Sci. 2014, 6, 195-219. [CrossRef] [PubMed]

4. Muro-Torres, V.M.; Soto-Jiménez, M.F.; Green, L.; Quintero, J.; Amezcua, F. Food web structure of a subtropical coastal lagoon. Aquat. Ecol. 2019, 53, 407-430. [CrossRef]

5. Odum, W.E.; Heald, E.J. The detritus-based food web of an estuarine mangrove community. Estuar. Res. Chem. Biol. Estuar. Syst. 1975, 1, 265-268.

6. Robertson, A.I.; Duke, N.C. Mangroves as nursery sites of fish and crustaceans in mangrove and other nearshore habitats in tropical Australia. Mar. Biol. 1987, 96, 193-205. [CrossRef] 
7. Robertson, A.I.; Blaber, S.J.M. Plankton, Epibenthos and Fish Communities. In Tropical Mangrove Ecosystems; Robertson, A.I., Alongi, D.M., Eds.; American Geophysical Union: Washington, DC, USA, 2007; Volume 41, pp. 173-224. [CrossRef]

8. Laegdsgaard, P.; Johnson, C. Why do juvenile fish utilize mangrove habitats? J. Exp. Mar. Biol. Ecol. 2001, 25, 229-253. [CrossRef]

9. Blaber, S.J.M.; Cyrus, D.P.; Albaret, J.J.; Ching, C.V.; Day, J.W.; Elliott, M.; Fonseca, M.S.; Hoss, D.E.; Orensanz, J.; Potter, I.C.; et al. Effects of fishing on the structure, functioning of estuarine, and nearshore ecosystems. ICES J. Mar. Sci. 2000, 57, 590-602. [CrossRef]

10. Hadwen, W.L.; Russell, G.L.; Arthington, A.H. Gut content-and stable isotope derived diets of four commercially and recreationally important fish species in two intermittently open estuaries. Mar. Freshw. Res. 2007, 58, 363-375. [CrossRef]

11. Abrantes, K.G.; Sheaves, M. Incorporation of terrestrial wetland material into aquatic food webs in a tropical estuarine wetland. Estuar. Coast. Shelf Sci. 2008, 80, 401-412. [CrossRef]

12. Giarrizzo, T.; Schwamborn, R.; Saint-Paul, U. Utilization of carbon sources in a northern Brazilian mangrove ecosystem. Estuar. Coast. Shelf Sci. 2011, 95, 447-457. [CrossRef]

13. Zagars, M.; Ikejima, K.; Kasai, A.; Arai, N.; Tongnunui, P. Trophic characteristics of a mangrove fish community in Southwest Thailand: Important mangrove contribution and intraspecies feeding variability. Estuar. Coast. Shelf Sci. 2013, 119, 145-152. [CrossRef]

14. Abrantes, K.G.; Johnston, R.; Connolly, R.M.; Sheaves, M. Importance of mangrove carbon for aquatic food webs in wet-dry tropical estuaries. Estuar. Coast. 2015, 38, 383-399. [CrossRef]

15. Rodelli, M.R.; Gearing, J.N.; Gearing, P.J.; Marshall, N.; Sasekumar, A. Stable isotope ratio as a tracer of mangrove carbon in Malaysian ecosystems. Oecologia 1984, 61, 326-333. [CrossRef]

16. Marguillier, S.; van der Velde, G.; Dehairs, F.; Hemminga, M.; Rajagopal, S. Trophic relationships in an interlinked mangrove-seagrass ecosystem as traced by $\delta 13 \mathrm{C}$ and $\delta 15$ N. Mar. Ecol. Prog. Ser. 1992, 151, 115-121. [CrossRef]

17. Bouillon, S.; Raman, A.V.; Dauby, P.; Dehairs, F. Carbon and nitrogen stable isotope ratios of subtidal benthic invertebrates in an estuarine mangrove ecosystem (Andhra Pradesh, India). Estuar. Coast. Shelf Sci. 2002, 54, 901-913. [CrossRef]

18. Sheridan, P.; Hays, C. Are mangroves nursery habitat for transient fishes and decapods? Wetlands 2003, 23, 449-458. [CrossRef]

19. Nagelkerken, I.; Van Der Velde, G. Are Caribbean mangroves important feeding grounds for juvenile reef fish from adjacent seagrass beds? Mar. Ecol. Prog. Ser. 2004, 274, 143-151. [CrossRef]

20. Kruitwagen, G.; Nagelkerken, I.; Lugendo, B.R.; Mgaya, Y.D.; Bonga, S.E. Importance of different carbon sources for macroinvertebrates and fishes of an interlinked mangrove-mudflat ecosystem (Tanzania). Estuar. Coast. Shelf Sci. 2010, 88, 464-472. [CrossRef]

21. Igulu, M.M.; Nagelkerken, I.; van der Velde, G.; Mgaya, Y.D. Mangrove fish production is largely fuelled by external food sources: A stable isotope analysis of fishes at the individual, species, and community levels from across the globe. Ecosystems 2013, 16, 1336-1352. [CrossRef]

22. Chong, V.C.; Low, C.B.; Ichikawa, T. Contribution of mangrove detritus to juvenile prawn nutrition: A dual stable isotope study in a Malaysian mangrove forest. Mar. Biol. 2001, 138, 77-86. [CrossRef]

23. Lee, S.Y. Exchange of organic matter and nutrients between mangroves and estuaries: Myths, methodological issues and missing links. Int. J. Environ. Sci. Technol. 2005, 31, 163-175.

24. Kristensen, D.K.; Kristensen, E.; Mangion, P. Food partitioning of leaf-eating mangrove crabs (Sesarminae): Experimental and stable isotope (13C and 15N) evidence. Estuar. Coast. Shelf Sci. 2010, 87, 583-590. [CrossRef]

25. Bui, T.H.H.; Lee, S.Y. Does 'you are what you eat' apply to mangrove grapsid crabs? PLoS ONE 2014, 9, e89074.[CrossRef]

26. Zetina Rejón, M.J.; Cabrera-Neri, E.; López-Ibarra, G.A.; Arcos-Huitrón, N.E.; Christensen, V. Trophic modeling of the continental shelf ecosystem outside of Tabasco, Mexico: A network and modularity analysis. Ecol. Model. 2015, 313, 314-324. [CrossRef]

27. Ruelas-Inzunza, J.R.; Páez-Osuna, F. Trophic distribution of $\mathrm{Cd}, \mathrm{Pb}$ and $\mathrm{Zn}$ in a food web from Altata-Ensenada del Pabellón subtropical lagoon, SE Gulf of California. Arch. Environ. Con. Toxicol. 2008, 54, 584-596. [CrossRef] 
28. Jara-Marini, M.E.; Soto-Jiménez, M.F.; Páez-Osuna, F. Mercury transfer in a subtropical coastal lagoon food web (SE Gulf of California) under two contrasting climatic condition. Environ. Toxicol. 2011, 30, 1611-1617. [CrossRef] [PubMed]

29. Mendoza-Carranza, M.; Hoeinghau, D.J.; Garcia, A.M.; Romero-Rodriguez, A.M. Aquatic food webs in mangrove and seagrass habitats of Centla Wetland, a Biosphere Reserve in Southeastern Mexico. Neotrop. Ichthyol. 2010, 8, 171-178. [CrossRef]

30. Jara-Marini, M.E.; Páez-Osuna, F.; Soto-Jiménez, M. Trophic Relationships Within a Subtropical Estuarine Food Web from the Southeast Gulf of California through Analysis of Stable Isotopes of Carbon and Nitrogen. In Fisheries Management of Mexican and Central American Estuaries; Amezcua, F., Bellgraph, B., Eds.; Springer: Berlin/Heidelberg, Germany, 2014; pp. 69-79. [CrossRef]

31. Thimdee, W.; Deein, G.; Sangrungruang, C.; Matsunaga, K. Analysis of primary food sources and trophic relationships of aquatic animals in a mangrove-fringed estuary, Khung Krabaen Bay (Thailand) using dual stable isotope techniques. Wetl. Ecol. Manag. 2004, 12, 135-144. [CrossRef]

32. Pinkas, L.; Oliphant, S.M.; Iverson, I.L.K. Food habits of albacore, bluefin tuna, and bonito in California waters. Fish Bulletin 1971, 152, 1-105.

33. Cortes, E. A critical review of methods of studying fish feeding based on analysis of stomach contents: Application to elasmobranch fishes. Can. J. Fish. Aquat. Sci. 1997, 54, 726-738. [CrossRef]

34. Post, D.M. Using stable isotopes to estimate trophic position: Models, methods, and assumptions. Ecology 2002, 83, 703-718. [CrossRef]

35. Amezcua, F.; Muro-Torres, V.; Soto-Jiménez, M.F. Stable isotope analysis versus TROPH: A comparison of methods for estimating fish trophic positions in a subtropical estuarine system. Aquat. Ecol. 2015, 49, 235-250. [CrossRef]

36. Minagawa, M.; Wada, E. Stepwise enrichment of N-15 along food-chains further evidence and the relation between delta-N-15 and animal age. Geochim. Cosmochim. 1984, 48, 1135-1140. [CrossRef]

37. Parnell, A.C.; Inger, R.; Bearhop, S.; Jackson, A.L. Source partitioning using stable isotopes: Coping with too much variation. PLoS ONE 2010, 5, e9672. [CrossRef] [PubMed]

38. Layman, C.A.; Arrington, D.A.; Montaña, C.G.; Post, D.M. Can stable isotope ratios provide quantitative measures of trophic diversity within food webs? Ecology 2007, 88, 42-48. [CrossRef]

39. Jackson, A.L.; Inger, R.; Parnell, A.C.; Bearhop, S. Comparing isotopic niche widths among and within communities: SIBER stable isotope Bayesian ellipses in R. J. Anim. Ecol. 2011, 80, 595-602. [CrossRef]

40. Swanson, H.K.; Lysy, M.; Power, M.; Stasko, A.D.; Johnson, J.D.; Reist, J.D. A new probabilistic method for quantifying n-dimensional ecological niches and niche overlap. Ecology 2015, 96, 318-324. [CrossRef]

41. Bouillon, S.; Connolly, R.M.; Lee, S.Y. Organic matter exchange and cycling in mangrove ecosystems: Recent insights from stable isotope studies. J. Sea Res. 2008, 59, 44-58. [CrossRef]

42. Chong, V.C. Mangroves-fisheries linkages-The Malaysian perspective. Bull. Mar. Sci. 2007, 80, 755-772.

43. Heithaus, E.R.; Heithaus, P.A.; Heithaus, M.R.; Burkholder, D.; Layman, C.A. Trophic dynamics in a relatively pristine subtropical fringing mangrove community. Mar. Ecol. Prog. Ser. 2011, 428, 49-61. [CrossRef]

44. Lugendo, B.R.; Nagelkerken, I.; Van Der Velde, G.; Mgaya, Y.D. The importance of mangroves, mud and sand flats, and seagrass beds as feeding areas for juvenile fishes in Chwaka Bay, Zanzibar: Gut content and stable isotope analyses. J. Fish Biol. 2006, 69, 1639-1661. [CrossRef]

45. Robertson, A.I.; Alongi, D.M.; Boto, K.G. Food chains and carbon fluxes. Tropical mangrove Ecosystem 41. Coast. Estuar. Stud. 1992. [CrossRef]

46. Gning, N.; Vidy, G.; Thiaw, O.T. Feeding ecology and ontogenic diet shifts of juvenile fish species in an inverse estuary: The Sine-Saloum, Senegal. Estuar. Coast. Shelf Sci. 2008, 76, 395-403. [CrossRef]

47. Lafaille, P.; Lefeubvre, J.C.; Schricke, M.T.; Feuteun, E. Feeding ecology of 0-group sea bass, Dicentrarchus labrax, in salt marshes of Mont Saint Michel Bay (France). Estuaries 2001, 24, 116-125. [CrossRef]

48. Gamito, S.; Pires, A.; Pita, C.; Erzini, K. Food availability and the feeding ecology of ichthyofauna of a Ria Formosa (South Portugal). Water Reservoir Estuar. Coast. 2003, 26, 938-948. [CrossRef]

49. Salgado, J.P.; Cabral, H.N.; Costa, M.J. Feeding ecology of the gobies Pomatoschistus minutus (Pallas, 1770) and Pomatoschistus microps (Kroyer, 1838) in the upper Tagus estuary, Portugal. Sci. Mar. 2004, 68, 425-434. [CrossRef] 
50. Amara, R.; Laffargue, P.; Dewarumez, J.M.; Maryniak, C.; Lagardère, F.; Luczac, C. Feeding ecology and growth of 0-group flatfish (sole, dab and plaice) on a nursery ground (Southern Bight of the North Sea). J. Fish. Biol. 2001, 58, 788-803. [CrossRef]

51. Sá, R.; Bexiga, C.; Veiga, P.; Vieira, L.; Erzini, K. Feeding ecology and trophic relationships of fish species in the lower Guadiana river estuary and Castro Marim e Vila Real de Santo Antonio saltmarsh. Estuar. Coast. Shelf Sci. 2006, 70, 19-26. [CrossRef]

52. Pasquaud, S.; Elie, P.; Jeantet, C.; Billy, I.; Martinez, P.; Girardin, M. A preliminary investigation of the fish food web in the Gironde estuary, France, using dietary and stable isotope analyses. Estuar. Coast. Shelf Sci. 2008, 78, 267-279. [CrossRef]

53. Hobson, K.A. Trophic relationships among high Arctic seabirds: Insights from tissue-dependent stable-isotope models. Mar. Ecol. Prog. Ser. 1993, 95, 7-18. [CrossRef]

54. Gurney, L.J.; Froneman, P.W.; Pakhomov, E.A.; Mc Quaid, C.D. Trophic positions of three euphausiid species from the Prince Edward Islands (Southern Ocean): Implication for the pelagic food web structure. Mar. Ecol. Prog. Ser. 2001, 217, 67-174. [CrossRef]

55. Bearhop, S.; Adams, C.E.; Waldron, S.; Fuller, R.A.; Susan, E.A.; Fullert, R.A.; Macleodj, H. Determining trophic niche width: A novel approach using stable isotope analysis. J. Anim. Ecol. 2004, 73, 1007-1012. [CrossRef]

56. Matthews, B.; Mazumder, A. A critical evaluation of intrapopulation variation of $813 \mathrm{C}$ and isotopic evidence of individual specialization. Oecologia 2004, 140, 361-371. [CrossRef] [PubMed]

57. Hutchinson, G.E. Population studies: Animal ecology and demography. Bull. Math. Biol. 1991, 53, $193-213$. [CrossRef]

58. Newsome, S.D.; Tinker, M.T.; Monson, D.H.; Oftedal, O.T.; Ralls, K.; Staedler, M.M.; Fogel, M.L.; Estes, J.A. Using stable isotopes to investigate individual diet specialization in California sea otters (Enhydra lutris nereis). Ecology 2009, 90, 961-974. [CrossRef]

59. Newsome, S.D.; Martinez del Rio, C.; Bearhop, S.; Phillips, D.L. A niche for isotopic ecology. Front. Ecol. Environ. 2007, 5, 429-436. [CrossRef]

60. Valdez-Hernández, J.I.; Ruiz-Luna, A.; Guzmán-Arroyo, M.; González-Farias, F.; Acosta-Velázquez, J.; Vázquez-Lule, A.D. Characterization of the Teacapán mangrove site-Agua Brava-Marismas Nacionales, Sinaloa-Nayarit. In Mangrove Sites with Biological Relevance and Ecological Rehabilitation Needs; National Commission for the Knowledge and Use of Biodiversity (CONABIO): Mexico City, Mexico, 2009.

61. Vinagre, C.; Salgado, J.; Costa, M.J.; Cabral, H.N. Nursery fidelity, food web interactions and primary sources of nutrition of the juveniles of Solea solea and S. senegalensis in the Tagus estuary (Portugal): A stable isotope approach. Estuar. Coast. Shelf Sci. 2008, 76, 255-264. [CrossRef]

62. Newell, R.I.E.; Marshall, N.; Sasekumar, A.; Chong, V.C. Relative importance of benthic microalgae, phytoplankton, and mangroves as sources of nutrition for penaeid prawns and other coastal invertebrates from Malaysia. Mar. Biol. 1995, 123, 595-606. [CrossRef]

63. Schwamborn, R.; Ekau, W.; Voss, M.; Saint-Paul, U. How important are mangroves as a carbon source for decapod crustacean larvae in a tropical estuary? Estuar. Coast. Shelf Sci. 2002, 229, 195-205. [CrossRef]

64. Tue, N.T.; Hamaoka, H.; Sogabe, A.; Quy, T.D.; Nhuan, M.T.; Omori, K. Food sources of macro-invertebrates in an important mangrove ecosystem of Vietnam determined by dual stable isotope signatures. J. Sea Res. 2012, 72, 14-21. [CrossRef]

65. Fry, B.; Ewel, K.C. Using stable isotopes in mangrove fisheries research. Isot. Environ. Health Stud. 2003, 39, 191-196. [CrossRef] [PubMed]

66. Rajkumar, M.; Perumal, P.; Prabu, V.A.; Perumal, N.V.; Rajasekar, T. Phytoplankton diversity in Pichavaram mangrove waters from the south-east coast of India. J. Environ. Biol. 2009, 30, 489-498. [CrossRef] [PubMed]

Publisher's Note: MDPI stays neutral with regard to jurisdictional claims in published maps and institutional affiliations. 